\title{
EVOLUTION AND STATE-OF-THE-ART OF COLUMN STABILITY CRITERIA
}

\author{
Reidar Bjorhovde \\ The Bjorhovde Group, P. O. Box 37198, Tucson, Arizona 85740-7198, USA \\ E-mail: rbj@bjorhovde.com
}

Received 23 Sept. 2009; accepted 28 Oct. 2009

\begin{abstract}
The strength and stability of steel columns have been the subjects of a great many studies since the original work of Leonhard Euler in 1744 and 1759. Numerous examinations of elastic buckling of perfectly straight columns were conducted during the $19^{\text {th }}$ century, the most famous being the studies of Engesser and Considère, with several series of column tests attempting to find agreement between theory and physical behavior. The research work continued in the $20^{\text {th }}$ century, examining the influence of material and member imperfections, including the famous tangent modulus work of Shanley, and the resolution of the effects of material non-linearity, residual stress and column out-of-straightness. The definitive solutions were only obtained in the 1970-s, when modeling and numerical solutions allowed for the incorporation of all nonlinear effects. Since that time reliability and probabilistic solutions have provided state-of-the-art criteria for limit state treatment of the column problem. These principles are now the bases of the design standards for columns in all of the countries in the world. The paper focuses on the major evolutions that have taken place, but especially the work over the past 40 years. Realistic treatment and representation of the strength of columns in actual structures have now been achieved by the engineering profession.
\end{abstract}

Keywords. columns, steel, stability, strength, theory, tests, nonlinear, limit states, reliability, design, standards.

\section{Introduction}

The strength and behavior of columns is one of the longest lasting, continuous research endeavors in the field of structural engineering. From the classical studies of Euler, Tredgold, Tetmajer, Considère, Engesser, von Karman, Shanley and others until today (Johnston 1981), the level of knowledge has advanced from understanding the characteristics of the elastic member to the current treatment of columns with material and geometric nonlinearities. The advancement has closely paralleled the evolution of testing and computational tools.

The most significant developments have taken place since the late 1960-s, and this was only possible because of the advent of electronic computing equipment. For example, the solution of the general, inelastic flexural buckling problem dates from that time, and studies of the influence of end restraint on inelastic columns were only finalized in the late 1990-s (Galambos 1998). In brief, the solution of two- and three-dimensional inelastic stability problems with randomly variable column strength parameters was far too complex for traditional closed-form techniques. Numerical solutions were the only option, and advances in testing equipment and measurement tools have allowed for close agreement between tests and theory.

A variety of column strength formulas have been developed over the years, being based on theoretical models or the results of column tests or combinations thereof. Some of these have appeared in design codes (also referred to as specifications or standards in this paper), but most have not survived the tests of time and useful- ness. However, even the most advanced of some of these approaches have suffered from certain drawbacks, whether caused by complexity in formulation, limited applicability or consistency for all types of members, or any number of other reasons.

At this point in time, however, the states-of-the-art of computation and testing have progressed so far that accuracy in modeling and realism in testing make it possible to expand the design criteria to take into account a number of additional features. For example, two-and three-dimensional response characteristics are incorporated into some advanced software, as is improved correlation and interaction between the column and the surrounding structure. Connection restraint is now built into some modeling schemes, and overall structural reliability has become a realistic feature of several international codes (AISC 2005a; CEN 2005).

Technical advances have significantly shortened the time lag between research results availability and code adoption. In some respects this is a desirable development; in other ways it has certain disadvantages. This is particularly so since too rapid acceptance may cause some, if not all, practical needs and implications to be overlooked. Contradictory as this may sound, it is nevertheless a fact that design criteria need a certain period of thought and practical maturation before they are adopted by a design standard. As an example (although not a stability consideration), the early incorporation of the initial bolted connection block shear provisions into the American steel design specification in 1978 led to a great number of difficulties. Since that time a number of 
researchers have advanced proposals for correct representation of limit states and improved design accuracy, but changes continue to be developed, including in the AISC code that was adopted in 2005 and further changes are proposed for the 2010 specification (AISC 2005a).

For the case of steel columns, the current level of knowledge reflects the fact that much effort has been devoted to evaluating practical applications of the strength and performance data that are available (Beer and Schulz 1970; Bjorhovde 1972, 1978, 1988; Galambos 1998; Ziemian 2010). It is a matter of record that the present amount of data and other information very significantly exceeds the size of the data base that was used to establish earlier column formulas. Improvements therefore can and have been made on the basis of factual results, with continuing improvements through earlier and current editions (Galambos 1998; AISC 2005a; CSA 2009; CEN 2005).

This paper will examine the most important of these developments, and also attempt to devise the course that may be suitable for design codes to continue to evolve.

\section{Elementary and advanced column stability concepts}

The basic mechanistic models of column strength and behavior can be categorized as follows, in ascending order of complexity:

(i) Individual pinned-end column, initially curved, inelastic material and/or structural response, incorporating residual stress, for example.

(ii) Individual column with restrained ends, initially curved, inelastic material and/or structural response, incorporating end restraint developed by members that frame into the column, for example.

(iii) The column is no longer an individual element, but part of a planar subassemblage of the structure. This consists of the member itself, with initial curvature, inelastic materials and/or structural response, and at least the immediately adjacent columns in the frame (above and below or in the same story). Actual end restraint effects may be taken into account by using the properties of actual connections, although the original model used rigid joints (Julian and Lawrence 1959; Galambos and Surovek 2008).

(iv) The column is one of the elements of the original planar structure, including all of the individual effects. The overall stability influence of framed and leaning columns is accounted for in this model.

(v) The column is part of a three-dimensional subassemblage, which incorporates end restraint, initial curvature and inelastic response characteristics. Failure may occur as flexural buckling about any axis, or as flexural-torsional buckling.

(vi) The column is one of the elements of a threedimensional frame. The model encompasses all conceivable strength and stiffness parameters, including the influence of leaning columns.

It is understood that any of the above mechanistic models may treat the column strength parameters as deterministic or probabilistic. In the latter case, the evalua- tion of the column stability will also incorporate the reliability aspects of the member and at least the subassemblage or the complete frame. In a limit states code format, this is required.

Model (i) was used by Euler for his classical solution. Model (ii) is that of the Engesser and Considère tangent modulus formulation, and Model (iii) was the state-of-the-art in the early 1970-s (Bjorhovde 1972; Johnston 1981; Galambos 1988, 1998; Ziemian 2010). Various forms of Model (iv) were developed through an intensive, international research effort in the 1980-s that led to realistic modeling and quantification of the restraint effects, including criteria for code implementation and design (Jones et al. 1980; Sugimoto and Chen 1982; Bjorhovde 1984; Bjorhovde et al. 1988, 1992).

Common to Models (i) through (iv) is the fact that they provide detailed theoretical solutions for the column strength, and the influences of the strength parameters are covered explicitly. Notwithstanding the limitations, the results are not subject to the random variations that are associated with tests. The sources, but not the magnitudes of the test variations are largely known, and emphasize the need for a very large body of test data if such are to serve as the sole basis for the design criteria (Bjorhovde 1972; Fukumoto and Itoh 1983; Hall 1983). Only an accurate theoretical model, whose performance can be verified by comparisons with test results, is capable of yielding the kind of rational design criteria which are not at the mercy of new test data at any time.

Models (v) through (viii) reflect progressively more accurate, but also significantly more complex approaches to the evaluation of the stability of columns as part of frameworks. In its original form, Model (v) was developed as an idealized, elastic buckling solution for a threestory column, with beams framing into the member with rigid connections (Julian and Lawrence 1959; Galambos 1988; Galambos and Surovek 2008). Using a slopedeflection analysis, the characteristic equation for the stability of the column as part of the subassemblage was obtained for the sway and non-sway cases. This led to the development of the well-known K-factor or effective length alignment charts (nomograms), which have been used extensively in design.

A number of studies examined the Model (v) solution of Julian and Lawrence (1959), assessing the effects of the assumptions that had been made. For example, Yura (1971) modified the elastic treatment to take into account inelastic buckling; this led to the formulation of the concept of the inelastic K-factor. Combined with the restraining effect of columns and the appropriate stiffness of beams and the far end support conditions, Johnston (1966) formulated a much-improved solution for columns in frames, and Yura expanded on this approach. This has since been expanded significantly (Hellesland and Bjorhovde 1996a, 1996b).

Last, but by no means least, Yura (1971) defined the concept of leaning columns, and provided a solution that considered their influence on overall frame stability. This has become increasingly important as a result of refinements in structural analysis techniques and computational 
equipment, as well as the advent of limit states design. Contemporary design codes take these influences into account through the so-called Direct Analysis Method (AISC 2005a; CSA 2009; CEN 2005).

In the last several years, a number of studies have addressed the issue of using realistic connection restraint characteristics in the assessment of column stability. Some of this has been reflected in the criteria for the strength of individual columns, as discussed for Model (iv). However, a major body of work has been devoted to incorporating such properties into the stability of columns in frame subassemblages. Numerous studies have offered improved understanding of the buckling mechanisms as well as how the end restraint concepts may be implemented in practice. The advantages of this approach is that it ties directly into what has been common practice for years, with well-defined physical modifications of known and accepted methods.

Model (vi) essentially expands the principles of Model (v), to incorporate the entire planar frame in the stability analysis. Beam-to-column connections are treated as rigid or pinned, or the actual moment-rotation response is used. The latter reflects the characteristics of semi-rigid connections, emphasizing the fact that realistic joints may exhibit elastic initial response, but the moment-rotation curve will sooner or later become nonlinear. Having developed the mechanistic concepts in Models (iii) through (v), arriving at a complete frame solution basically requires only additional computational capacity. However, it is noted that the word "only" can be misleading. This is especially true if semi-rigid connections are used, and/or if three-dimensional response characteristics are to be incorporated.

For almost all structural types, notably those with substantial gravity and/or lateral loads from wind or seismic action, second order effects are critical. This applies whether the frame is braced or unbraced, although the latter tends to be more affected. The original research work and the solution for these P-delta effects were provided by $\mathrm{P}$. F. Adams while he was a Ph.D. graduate student at Lehigh University; details of the historical evolution have been provided by Galambos (1988).

The last number of years has seen significant progress in the work towards developing practical analysis methods and design criteria for frames with semi-rigid connections. All major international design codes contain provisions for such designs, but actual use is still limited, primarily because of the lack of practical software, but connection modeling is another major issue. Data bases for certain types of connections have been developed (Nethercot 1985; Kishi and Chen 1986), but the real problem lies with the fact that it is near-impossible to make use of actual test data in practical design situations. The approach that appears to offer the most useful procedure is based on a classification system for the connections, focusing on the key characteristics of the momentrotation behavior (Bjorhovde et al. 1990; CEN 2005).

Model (vii) is the three-dimensional version of Model (v). Model (viii) represents the extension of Model (vi); it is an all-encompassing, three-dimensional analysis of a full frame, Numerous studies reflect the state-of-theart of 3D subassemblage analysis and testing, including the potential development of standardized test methods. These appear to provide the bridge of understanding to the complete frame evaluation (Nethercot 1992; Celikag and Kirby 1988; Janss et al. 1988).

Although most designers still prefer to use elastic methods of analysis and design, and there are a great many software packages available for such work, more advanced researchers and designers now have gone to complete inelastic analyses. State-of-the-art codes and standards have adopted such procedures (AISC 2005a; CSA 2009; CEN 2005), especially when seismic response has to be taken into account (AISC 2005b). And in a major development towards inelastic design, the forthcoming (2010 edition) AISC code will have a comprehensive section on design by inelastic analysis. The 2010 edition is just about complete at this time; it will be published early next year. Several studies have already examined the proposed procedures, and although the method is very complex and likely will only be used by advanced designers, the method offers a clear view where contemporary design criteria are headed (White and Hajjar 1997a; 1997b; Surovek et al. 2005; White and Goverdhan 2008).

The preceding has given an overview of the history and the status of the stability treatment of individual columns and columns as part of frameworks. The tendency today is to move towards the evaluation of the complete structure. However, a majority of the design criteria have been and will continue to be based on individual members. The better the data base for structural elements, therefore, the better will be the design procedures, and the easier will be the transition to the full structure.

\section{Mechanistic versus empirical modeling}

The preceding has demonstrated that much has been done to develop mechanistic column response models. Further, over the years a substantial number of column tests have been conducted, in some cases only to verify theoretical solutions. In other projects, however, series of tests have been carefully planned and executed, to cover all of the column strength variables, with the specific aim of arriving at experimentally based design criteria. Wellknown examples of the latter are the column tests of Tetmajer and von Karman (Johnston 1981). Among the more recent tests are the series of the European Convention of Constructional Steelwork (ECCS) (Sfintesco 1970; Jacquet 1970) that were conducted to verify and supplement the theoretical studies of Beer and Schulz (1970) in arriving at the ECCS, now the Eurocode 3 column curves (CEN 2005).

Data gathering efforts have also been undertaken, mostly to arrive at test-based column curves, using experiments that have been carried out in a number of different locales. Prominent among these studies are the work of Fukumoto and Itoh (1983) and Hall (1983). Both examined large numbers of test data, and eventually proposed column curves for use with design standards. 
Both of the fundamental approaches that have been described in the preceding have been used to develop column design curves and other criteria. In addition, a number of studies have aimed at devising mathematically simple equations and curves that approximate those with an engineering theory background, but otherwise offer no physical interpretation. The work of Rondal and Maquoi (1979) and Rotter (1982) are the most comprehensive of these efforts.

The most significant benefit of using mechanicsbased column curves is their predictability and replication of test results. In addition, a model that offers clear physical significance and solid grounding in mechanics has a definite advantage. In other words, given the material properties and other relevant member data, these column curves can be used to predict the outcome of physical tests. The more column strength parameters that are incorporated into the model, the closer will be the values of the theoretical and the physical strengths. Thus, column models (iii) and (iv) of the preceding chapter of this paper are generally capable of producing results that are within 5 percent of the experimental data (Bjorhovde 1972, 1988; Galambos 1988, 1998; Ziemian 2010).

Many such column curves have been developed over the years. For example, the formula of the Column Research Council (CRC), the so-called CRC Curve, was used for many years as the basis for the allowable stress design specification in USA. It reflected the tangent modulus solution for a perfectly straight column with residual stress. The three SSRC Curves that were developed by Bjorhovde (1972, 1988) were maximum strength solutions, taking into account residual stress as well as initial out-of-straightness, and also incorporated the random nature of all of the column strength parameters. These curves were a perfect fit for a code that would be based on limit states principles, which was done for the US in the late 1970-s and early 1980-s (Johnston 1976; Galambos 1988, 1998; Ziemian 2010). The Canadian steel design code adopted SSRC Curve 2 in 1974; subsequently SSRC Curve 1 was added, such that the CSA code has used two column curves since 1989 (CSA 2009). Finally, SSRC Curve 2P has been the column curve for the limit states (LRFD) criteria of the US since 1986 (AISC 2005). The column criteria of Eurocode 3 (CEN 2005) are based on the work of Beer and Schulz (1970).

The major drawback of the test-based approach is that without a mechanistic base, any new test results would have to be incorporated into the data base for the design curve. This might necessitate changes in the curve, and such changes would have to be made any time new steel shapes and other products were developed by the steel industry. Apart from the impractical aspect of having a basic design curve change every so often, and only as a result of certain test data, the real problem is rooted in the fact that test results are subject to interpretation. In other words, due to the many factors that influence the column strength, the outcome of an experiment is not always clearly understood, much less properly interpreted. Some of the parameters are not easily quantified, there is a certain amount of interaction among others, and yet others may not have been recognized as playing a role.

On this background, it is clear that a proper and reliable column strength criterion is one that gives excellent correlation between tests and theory, and that takes explicitly into account all of the major strength parameters. Such can only be achieved with an accurate mechanistic model.

\section{Some column strength considerations}

Due to the complexity of the inelastic flexural buckling problem, all of the primary strength parameters were not included in the analyses until adequate computational tools were available. Previously, closed form solutions were always sought. As a result, it was feasible to take into account the presence of residual stresses, but initial crookedness could only be considered through stressbased analyses. For example, the secant formula did this by an elastic flexural analysis which limited the maximum stress in the cross section to yielding. Similar attempts were made to include restraint effects.

The following gives a condensed review of the evolution of column modeling through the stages of parameter incorporation.

\subsection{Influence of residual stress}

Very well known and documented, through extensive tests and analyses, residual stress is one of the main column strength parameters. Residual stress data are available for a variety of shapes, sizes, grades of steel and manufacturing practices, including the influence of welding and flame cutting. Some limitations still exist for the very heavy structural shapes, although additional measurement results and computational data are becoming available.

Column formulas around the world have incorporated the influence of residual stress since the 1950-s. The initial applications were all based on tangent modulus formulations (Johnston 1981).

\subsection{Straightening effects}

Much of the residual stress data that have been mentioned represent those of hot-rolled and welded built-up shapes, mostly of the wide-flange or $\mathrm{H}$ - or I-type. However, it has been common practice in steel mills for years to straighten the shapes to meet tolerance requirements. The straightening is either continuous (rotary straightening) or point-applied (gag straightening), but common to both methods is the fact that the operation is performed at room temperature. Such cold-straightening has a significant influence on the residual stress magnitudes and distributions within a shape.

Test results are limited, as are theoretical evaluations, but it is known that continuous cold-straightening will lead to lower compressive residual stresses, and therefore higher column strength. It is more pronounced for small to medium size shapes; for heavy shapes it is doubtful 
whether gag straightening has much of an overall influence (Brozzetti et al. 1970; Aschendorff et al. 1983).

Although current column models are capable of incorporating cold-straightening effects, the lack of a large body of cohesive, carefully developed residual stress data has prevented design codes from taking advantage of the benefit. Further research is clearly needed.

\subsection{Out-of-straightness effects}

Crookedness was recognized early as a major factor in the column strength equation, but the difficulty of obtaining closed form solutions prevented it from being adopted into design codes. The most common approach was to use a variable factor of safety to account for the effects of the crookedness. This solution was chosen by a number of design standards. For example, the American allowable stress design criteria continue to utilize a factor of safety that varies from 1.67 to 1.92 , covering the combined effects of out-of-straightness, load eccentricity and so one.

Current limit states design criteria (AISC 2005; CSA 2009; CEN 2005) cover the crookedness effects explicitly by using the column maximum strength as the basic criterion. This was made feasible when computer technology allowed for numerical solutions of the inelastic loaddeflection column problem. Some standards have focused on the maximum value of the initial out-of-straightness; this is commonly around 1/1000 of the member length. The Canadian (CSA 2009) and the European (CEN 2005) codes have chosen this approach. The American limit states standard (AISC 2005) uses the mean value of l/1500 of the length, on the premise that in the first order, second moment approach to limit states design, all parameters use the mean as the key central tendency. The value of $1 / 1500$ is based on probabilistic evaluations of the out-ofstraightness effects (Bjorhovde 1972).

\subsection{Some other considerations}

Overall frame stability and methods of taking actual connection characteristics into account continue to be among the major research efforts today. This is reflected by the international steel connection workshops that have been arranged every four years since 1987. The first such workshop addressed the great variety of structural connections and how their properties could be built into frame analysis and stability considerations (Bjorhovde et al. 1988). The use and design of frames with semi-rigid connections (called PR connections in USA) continues to be the subject of major projects, and a large number of papers continue to address the subject (for example: Bjorhovde et al. 1990; Deierlein 1992; Christopher and Bjorhovde 1999; Surovek et al. 2005; White and Goverdhan 2008).

\section{Structural safety, strength and economy}

In engineering terms, safety is the issue of overriding concern, but strength is easier to address. Therefore, design criteria have tended to focus on achieving adequate safety by setting the strength requirements sufficiently low. Albeit an admirable goal, the lack of attention to the variability of the strength parameters has typically led to highly variable factors of safety in allowable stress design. The American allowable stress design criteria offer a good example, where the theoretical column safety for a range of member types and sizes ranged between 1.67 and 1.92 , but the actual safety margins varied from 1.4 to 2.5 (Bjorhovde 1978).

Economy, on the other hand, is an elusive concept. It is possible to estimate structural costs by considering the amount of steel and other materials that are used. However, this does not address fabrication and construction costs, for instance, and these can vary substantially from one area to another. For the designer, therefore, the key issue is to concentrate on providing as accurate calculations as possible, and this is helped significantly by accurate design requirements. In other words, the more of the stiffness and strength parameters that are taken into account in the code, the better will be the resulting structure.

In the evolution of the column stability criteria, it is a fact that more and more of the important strength parameters have been incorporated into the code equations. Thus, the column curves of today reflect residual stress and initial out-of-straightness through the maximum strength concept, and the limit states format allows for the random variability of these and the other factors of influence (material properties, geometry of the cross section, etc.). Safety is therefore achieved in the best possible fashion. Future refinements of the column criteria therefore should only be regarded in conjunction with the improvements that are currently being contemplated for the overall design of the frame. This is clearly the direction that needs to be pursued for the future.

\section{Summary and conclusions}

A comprehensive review has been provided of the development of the column stability criteria as they have appeared in research studies and design codes for the past 40 years. It is demonstrated that through improved analytical and experimental techniques, all of the major strength parameters are now explicitly accounted for in the primary design codes in the world. The advantages of mechanics-based formulations of the design criteria are explained in detail, offering the rationale for code development that is not subject to short-term market variations.

\section{References}

American Institute of Steel Construction (AISC) 2005a. Specification for Structural Steel Buildings, ANSI/AISC Standard 360/05, AISC, Chicago, Illinois, USA.

American Institute of Steel Construction (AISC). 2005b. Seismic Provisions for Structural Steel Buildings, ANSI/ AISC Standard 341/05, AISC, Chicago, Illinois, USA.

Aschendorff, K. K.; Bernard, A.; Bucak, O.; Mang, F. and Plumier, A. 1983. Buckling Tests on Heavy Rolled I-Shapes in St 37 and St 52, and in St E 460 with Standard Sizes, Der Bauingenieur 58: 261-268 (in German).

Beer, H. and Schulz, G. 1970. Theoretical Bases for the European Buckling Curves, Construction Métallique 7(3): 3755) (in French). 
Bjorhovde, R. 1972. Deterministic and Probabilistic Approaches to the Strength of Steel Columns, Ph.D. dissertation, Lehigh University, Bethlehem, Pennsylvania, USA.

Bjorhovde, R. 1978. The Safety of Steel Columns, Journal of the Structural Division, ASCE 104(ST-3): 463-477.

Bjorhovde, R. 1984. Effect of End Restraint on Column Strength - Practical Applications, Engineering Journal, AISC 20(1): 1-13.

Bjorhovde, R. 1988. Columns: From Theory to Practice, Engineering Journal, AISC 25(1): 21-34.

Bjorhovde, R.; Brozzetti, J. and Colson, A. 1988. Connections in Steel Structures: Behaviour, Strength and Design, Elsevier Applied Science, London, England.

Bjorhovde, R.; Colson, A. and Brozzetti, J. 1990. Classification System for Beam-to-Column Connections, Journal of Structural Engineering, ASCE 116(11): 3063-3080. doi:10.1061/(ASCE)0733-9445(1990)116:11(3059)

Bjorhovde, R.; Colson, A.; Haaijer, G. and Stark, J. W. B. 1992. Connections in Steel Structures II, AISC, Chicago, Illinois, USA.

Bjorhovde, R.; Colson, A., and Zandonini, R. 1996. Connections in Steel Structures III, Pergamon - Elsevier Applied Science, London, England.

Bjorhovde, R.; Bijlaard, F. S. K. and Geschwindner, L. F. 2008. Connections in Steel Structures VI, AISC, Chicago, Illinois, USA.

Canadian Standards Association (CSA). 2009. Steel Structures for Buildings, CSA Standard S16-2009, CSA, Mississauga, Ontario, Canada.

Celikag, M. and Kirby, P. A. 1988. Standardized Method for Measuring 3-D Response of Semi-Rigid Joints, in Bjorhovde, R., Brozzetti, J. and Colson, A. (Eds.). Connections in Steel Structures - Behaviour, Strength \& Design, Elsevier Applied Science, London, UK, 203-210.

Christopher, J. E. and Bjorhovde, R. 1999. Semi-Rigid Frame Design Methods for Practicing Engineers, Engineering Journal, AISC 36(1): 12-28.

Comité Europeén de Normalisation (CEN). 2005. Eurocode 3 Design of Steel Structures, Standard 1993-1, CEN, Brussels, Belgium.

Deierlein, G. G. 1992. An Inelastic Analysis and Design System for Steel Frames with Partially Restrained Connections, in Bjorhovde, R., Brozzetti, J. and Colson, A. (Eds.). Connections in Steel Structures - Behaviour, Strength \& Design, Elsevier Applied Science, London, UK, 408-417.

Fukumoto, Y. and Itoh, Y. 1983. Evaluation of Multiple Column Curves from the Experimental Data Base Approach, Journal of Constructional Steel Research 3(3): 2-19. doi:10.1016/0143-974X(83)90002-0

Galambos, T. V.; Editor. 1988. Guide to Stability Design Criteria for Metal Structures, $4^{\text {th }}$ Ed., John Wiley \& Sons, New York, NY, USA.

Galambos, T. V.; Editor. 1998. Guide to Stability Design Criteria for Metal Structures, $5^{\text {th }}$ Ed., John Wiley \& Sons, New York, NY, USA.

Galambos, T. V. and Surovek, A. E. 2008. Structural Stability of Steel - Concepts and Applications for Structural Engineers, John Wiley \& Sons, New York, NY, USA.

Hall, D. H. 1983. Proposed Steel Column Design Criteria, Journal of Structural Engineering, ASCE 109(9): 20862096.
Hellesland, J. and Bjorhovde, R. 1996a. Restraint Demand Factors and Effective Lengths of Braced Columns, Journal of Structural Engineering, ASCE 122(10): 1216-1224. doi:10.1061/(ASCE)0733-9445(1996)122:10(1216)

Hellesland, J. and Bjorhovde, R. 1996b. Improved Frame Stability Analysis with Effective Lengths, Journal of Structural Engineering, ASCE 122(11): 1275-1283. doi:10.1061/(ASCE)0733-9445(1996)122:11(1275)

Janss, J.; Jaspart, J. P. and Maquoi, R. 1988. Strength and Behaviour of In-Plane Weak Axis Joints and of 3-D Joints, in Bjorhovde, R.; Brozzetti, J. and Colson, A. (Eds.). Connections in Steel Structures - Behaviour, Strength \& Design, Elsevier Applied Science, London, UK, 60-68.

Jacquet, J. 1970. Column Buckling Tests and Their Statistical Evaluation, Construction Métallique 7(3) (in French).

Johnston, B. G. 1966. Editor. Guide to Design Criteria for Metal Compression Members, $2^{\text {nd }}$ Edition, Column Research Council, John Wiley \& Sons, New York, NY, USA.

Johnston, B. G. 1976. Editor. Guide to Stability Design Criteria for Metal Structures, $3^{\text {rd }}$ Edition, Structural Stability Research Council, John Wiley \& Sons, New York, NY, USA.

Johnston, B. G. 1981. Column Buckling Theory: Historical Highlights, Journal of the Structural Division, ASCE 107(ST-4, April): 649-670.

Jones, S. W.; Kirby, P. A. and Nethercot, D. A. 1980. Effect of Semi-Rigid Connections on Steel Column Strength, Journal of Constructional Steel Research 1(1): 35-46. doi:10.1016/0143-974X(80)90007-3

Julian, O. G. and Lawrence, L. S. 1959. Notes on S \& L Nomograms for Determination of Effective Lengths. Unpublished Report, Jackson \& Moreland Engineers, Boston, Massachusetts, USA.

Kishi, N. and Chen, W.-F. 1986. Data Base of Steel Beam-toColumn Connections. Vols. I and II, Structural Engineering Report No. CE-STR-86-26, Purdue University, West Lafayette, Indiana, USA.

Nethercot, D. A. 1985. Steel Beam to Column Connections - A Review of Test Data and Their Applicability to the Evaluation of the Joint Behaviour of the Performance of Steel Frames. CIRIA, London, England.

Nethercot, D. A. 1992. Behaviour of Semi-Rigid Connections and Implementation in Frame Design, in Bjorhovde, R.; Brozzetti, J. and Colson, A. (Eds.). Connections in Steel Structures - Behaviour, Strength \& Design, Elsevier Applied Science, London, UK, 360-369.

Rondal, J. and Maquoi, R. 1979. Single Equation for SSRC Column Strength Curves, Journal of the Structural Division, ASCE 105(ST1): 247-250.

Rotter, J. M. 1982. Multiple Column Curves by Modifying Factors, Journal of the Structural Division, ASCE 108(ST7): 1665-1669.

Sfintesco, D. 1970. Experimental Basis for the European Column Curves, Construction Métallique 7(3) (in French).

Sugimoto, H. and Chen, W.-F. 1982. Small End Restraint Effects on Strength of H-Columns, Journal of the Structural Division, ASCE 108(ST3): 661-681.

Surovek, A. E.; White, D. W. and Leon, R. T. 2005. Direct Analysis for Design Evaluation and Design of PartiallyRestrained Steel Framing Systems, Journal of Structural Engineering, ASCE 131(9): 1376-1389. doi:10.1061/(ASCE)0733-9445(2005)131:9(1376) 
White, D. W. and Hajjar, J. F. 1997a. Buckling Models and Stability Design of Steel Frames: a Unified Approach, Journal of Constructional Steel Research 42(3): 171-207. doi:10.1016/S0143-974X(97)00014-X

White, D. W. and Hajjar, J. F. 1997b. Design of Steel Frames without Consideration of Effective Length, Engineering Structures 19(10): 797-810.

doi:10.1016/S0141-0296(97)00161-2

White, D. W. and Goverdhan, A. V. 2008. Design of PR Frames Using the AISC Direct Analysis Method, in Bjorhovde, R.,
Brozzetti, J. and Colson, A. (Eds.). Connections in Steel Structures - Behaviour, Strength \& Design, Elsevier Applied Science, London, UK, 255-264.

Yura, J. A. 1971. The Effective Length of Columns in Unbraced Frames, Engineering Journal, AISC 8(2): 37-42.

Ziemian, R. D. 2010. Guide to Stability Design Criteria for Metal Structures, $6^{\text {th }}$ Ed., John Wiley \& Sons, New York, NY, USA. doi:10.1002/9780470549087

\section{KOLONŲ PASTOVUMO KRITERIJŲ RAIDA IR ŠIUOLAIKINĖ BŪKLE்}

\section{R. Bjorhovde}

\section{Santrauka}

Plieninių kolonų stiprumas ir pastovumas buvo daugelio tyrinëjimų objektas, pradedant nuo originalių Leonhardo Eulerio 1744 ir 1759 m. darbų. XIX a. buvo atlikta daugelis idealiai tiesių kolonų tampriojo klupumo tyrimų iš kurių žymiausi buvo Engesero (Engesser) ir Konsiderès (Considere) tyrimai, apėmę kelias kolonų bandymų serijas. Jais siekta rasti dermę tarp teorijos ir fizinès elgsenos. Darbai buvo tęsiami ir XX a., nagrinèjant medžiagų ir elementų nuokrypių poveiki, įskaitant gerai žinomą Šenlio (Shanley) liestinès modulio darbą, ir medžiagų netiesiškumo, liekamujų itempių bei kolonų išklupimo poveikius. Galutiniai sprendiniai buvo gauti tik $1970 \mathrm{~m}$., kai modeliavimas ir skaitiniai eksperimentai leido atsižvelgti i visus netiesinius poveikius. Nuo to laiko patikimumo ir tikimybiniai sprendiniai suteike šiuolaikinius kriterijus kolonų problemos ribinių būvių traktuotei. Dabar šie principai yra visų pasaulio šalių kolonų projektavimo normų pagrindas. Straipsnyje pristatytos pagrindinès raidos kryptys, apžvelgiamas darbas, nuveiktas per pastaruosius 40 metų. Statybos profesionalai pasiekè tikrovišką dabartinių statinių kolonų stiprumo traktuotę ir pateikimą.

Reikšminiai žodžiai: kolonos, plienas, pastovumas, stiprumas, teorija, bandymai, ribiniai būviai, patikimumas, projektavimas, normos.

Reidar BJORHOVDE is a President of The Bjorhovde Group, a consulting firm and international engineering consortium located in Tucson, Arizona, U S A. With doctoral degrees from the Norwegian Institute of Technology and Lehigh University, Dr. Bjorhovde was a professor at the University of Alberta, the University of Arizona and the University of Pittsburgh for many years. He is Editor of the Elsevier Journal of Constructional Steel Research and the Research Editor of the AISC Engineering Journal. Dr. Bjorhovde has conducted extensive consulting, teaching and research work, including landmark studies on the stability and reliability of steel columns, structural steel connections, steel materials and composite structures. The author of more than 250 archival publications, he has presented more than 500 lectures in various countries. Dr. Bjorhovde has received many awards, among them the prestigious Higgins Award of AISC, the NATO Senior Science Fellowship, the ASCE George Winter Award and the Lynn S. Beedle Award of the Structural Stability Research Council. He is a Fellow of ASCE and an Honorary Fellow of the Singapore Structural Steel Society, and a member of numerous professional and scientific organizations. He is a Registered Professional Engineer in the United States, Canada and Norway. He is a member of the American steel design code committees of AISC and AISI and of the Canadian steel design code committee CSA S16. 